\title{
NATIONALITY IN BRAZILIAN LAW
}

Paulo Cesar Villela Souto Lopes Rodrigues

$\mathrm{PhD}$ in international law. He teaches Public International Law at the Universidade de Brasília

E-mail:smjc@hotmail.com

Stephen Edem Gbedemah

Graduated in International Relations at the Universidade de Brasília

E-mail: stephen.delaedem@gmail.com

Received: 2016-07-10. Accepted:2017-11-26

\begin{abstract}
This paper aims to present the rules of nationality in brazilian law. Therefore, it will demonstrate the constitutional cases of how nationality can be acquired and lost; and the possible distinctions between birth and naturalized nationals in the brazilian law.
\end{abstract}

Keywords: nationality - brazilian law - naturalization

\section{NATIONALITY}

Nationality ${ }^{1}$ is the legal and political bond that links an individual

1 MARINHO, Ilmar Penna. Tratado Sobre a Nacionalidade. Volume Primeiro. Direito Internacional da Nacionalidade. Rio de Janeiro: Departamento de Imprensa Nacional, 1956. pp. 13-15: "Nationality is a word that can be understood in two different meanings: a broad, sociological meaning; the other, restricted, legal.

In the first sense, the word nationality lends itself to numerous literary dilettantes and extensive philosophical ramblings. Therefore, they have many dedicated writers, philosophers and sociologists who, in fascinating musings, run background ethnic through all ranges of people. In the legal sense, which only interests us in this work, nationality has a precise character, a defined concept, a limited field of action. It appears as a political quality of socialized man. The man who abandons the tribe, the clan. The man who is part of the perfect social organization the State.

This basic difference between the two notions of nationality is absolutely essential because, through it, we are able to see how and why the terms nationality, nation and national are used to determine two quite distinct phenomena: one, the ethnic group; the other, the political group. [...]" 
to a sovereign state. It is a bond because it entails rights and obligations. Rights as to enter and stay in the territory and to receive diplomatic protection; obligations such as military service and, in Brazil, to vote ${ }^{2}$. It is legal because it's regulated by law, while other areas of the humanities it is occupying. It is political because pointing out who is a national, is a political choice. Legally, as a rule, the constitutional order of the State is what establishes who are its nationals ${ }^{3}$. Politically, deciding who they are is the decision taken at the very formation of the state. This decision is taken both at the creation of the state, by the ordinary constituent power; and in its possible subsequent configuration, via the derived constituent power.

The state is made up of three elements: territory, government (or sovereignty) and people. People are the set of nationals which in addition to the mentioned legal and political bond, generally have a common identity: ethnic, cultural, religious and idiomatic. However, the nationality is much more closely related to the concept of State, as a political organization than with the idea of a nation as a cultural or sociological phenomenon ${ }^{4}$.

The concept of sovereignty can be understood under dual focus: (i) internally, as a monopoly of the legitimate use of violence and force; and (ii) externally, as insubordination to a foreign State. The concept of sovereignty in the external perspective, understand, includes the right to decide who is its national, not admitting that another State determines who will be its national other than its own self.

It is important to note that not everyone who occupy the territory of a State are its nationals. The number of people in the territory of a sovereign State form the concept of population. People, as a State element, is the national assembly. All others will be foreigners. It is the opposite of the national that we extract the concept of the foreigner ${ }^{5}$, no matter what condition the individual who is not a national is on the territory: in a regular or an irregular situation, national of this or that country, or even if does not bear any nationality. National of another State, refugee, asylum, stateless, regular, temporary or permanent,

2 Article $14, \S 1^{\circ}$, I, of the Brazilian Constitution.

3 In Brazil, article 12, section I and II of the Constitution establishes who are Brazilian nationals. 4 Phenomenon that can be perceived in an objective form, as a group of individuals who have the same language, ethnicity, religion, culture and shared history; and, in the subjective aspect, as a group of individuals who perceive and declare themselves as a nation. What is important, therefore, to the legal concept of nationality, is to linked the individuals legally and politically to a sovereignty, so that, the nations are not what make states and nationalisms, but the opposite. HOBSBAWM, Eric J. Nações e Nacionalismo desde 1780. 5a ed. São Paulo: Paz e Terra, 2008. pp.14-20.

5 CAHALI, Yussef Said. Estatuto do Estrangeiro. $2^{\text {a }}$ ed. Revista, atualizada e ampliada. São Paulo: Editora Revista dos Tribunais, 2010. p. 26. 
merely irregular or illegal, tourist, businessman or religious missionary, everyone who is not a national is a foreigner.

\subsection{General Doctrine}

The right to nationality bears legal nature to fundamental rights, recognizing in its concession, compliance with universally recognized as protective values of human dignity.

The Article 15 of the Universal Declaration of Human Rights states: "Everyone has the right to a nationality". The American Convention on Human Rights, in its turn, establishes in its Article 20, which deals with the right to nationality that " 1 - Everyone has the right to a nationality; 2 - Everyone has the right to the nationality of the State in whose territory he was born if he does not have the right to any other nationality; 3 No one shall be arbitrarily deprived of his nationality or of the right to change it".

Nationality provides people with a sense of belonging, of identity, of communion with a particular community, but not only this. It creates a series of obligations and duties and, more importantly, allows the exercise of any number of rights which they would be denied if they were considered foreigners.

Aware of these issues, the United Nations urged the States in two Conventions (the 1954 Convention on the Status of Stateless Persons and the 1961 to Reduce Statelessness) that they should not cease to give, with the most generous possible criteria, the fundamental right to nationality.

The right to a nationality corresponds also to the rights to change one's nationality and not to change it. The right to change acknowledges the right to renounce a nationality and the right to acquire another nationality. In this last situation, most times, the acquisition of a new nationality (right to acquire) means the loss of the previous nationality (right to lose). The right not to change is identified with the right not to acquire, as with people who are in annexed territories by other States; and the legal status of married women who recognize the right not to acquire the nationality of her husband by marriage (in this case, when there is the acquisition of nationality by women, because marriage, has the granting of nationality by the will of the law). The right not to lose can be illustrated with the example of annexation of territory, in which the national of the former State intends to remain a national of the former ${ }^{6}$. Also with respect to the right to not lose, Article 15 of the Universal Declaration of Human Rights, in addition to providing that "Everyone has the right to a nationality", states that "No one shall be

6 DOLINGER, Jacob. Direito Internacional Privado. Parte Geral. $7^{\text {a }}$ ed. Ampliada e Atualizada com as Emendas à Constituição e o novo Código Civil. Rio de Janeiro: Renovar, 2003. p.163. 
arbitrarily deprived of his nationality nor denied the right to change nationality".

In relation to the right not to acquire, the 1930 The Hague Convention on Nationality, states that the children of diplomats on mission abroad have the right not to acquire the nationality of their place of birth, just the mere resignation of it is enough for them to get rid of the nationality and the obligations that came along.

Two concepts usually confused, but that do not have anything in common are nationality and citizenship ${ }^{7}$, although lots of countries call their nationals citizens. Nationality, like we saw, is a legal and political bond between an individual and a sovereign State, while citizenship is, in the legal sense, the ability to exercise political rights. The confusion between the terms ${ }^{8}$, in the States that identify, would entail, among other things, the historical construction of citizenship in American law, some national - the native Indians of the North American territory - would not be citizens, so-called noncitizen nationals. Extended citizenship to all nationals without distinction of origin, became taking a term to mean another, identifying nationals as citizens.

To understand the distinction clearly, just consider the situation of a Portuguese living in Brazil, under the Federal Constitution, he has equal rights like those of a naturalized Brazilian'. This Portuguese national can exercise Brazilian citizenship, vote and be voted for, and will not be a Brazilian national. The same happens with the nationals of members states of the European Union that while they are not nationals of the union, because Europe is not a State, they are European citizens, because they exercise political rights together with this legal body of public international law.

Even today, there are grey areas between the two concepts. Antony Aust, studying the different species of British citizenship, states that the term citizenship usually denotes broad enjoyment of civil and political rights in a national state, and citizenship and nationality generally coincide. ${ }^{10}$

\footnotetext{
7 Ibidem pp. 156-160.
}

8 In the Classical Antiquity, prior to the formation of modern states, citizenship was a condition, a position in society. It was the linking of the individual with the things of the city, their ability to participate in decisions that concern everyone in the city. Fustel de Coulanges remembers that this position stems, especially in Greece, the participation of the individual in the service of their religious practice in the city. In Rome, issues such as the origin, precede religious communion which gives the social status of citizen, with all its legal consequences.

9 Friendship, Cooperation and Trade Treaty between the Federative Republic of Brazil and Portugal. Article 12

10 AUST, Antony. Handbook of International Law. 2a reprinted. Cambridge: Cambridge University Press, 2009. p. 180: “The term 'citizenship' usually denotes entitlement, under the law of a state, to full civil and political rights, and citizenship and nationality normally coincide. 
The doctrine stresses a need for a greater separation of concepts, distinguishing, nationality and citizenship ${ }^{11}$, so that, in addition to the distinction already made between the concepts of nationality and citizenship, the place of birth would be a territorial concept (naturality), referring only to the place where the person proceeds, which may possibly coincide with the government granting him citizenship. Thus, a person may have the nationality of the country where he was born; can possibly be a citizen of the place where he was born and from where he is a national, but that does not necessarily mean that this person will be natural, national and citizen of the same country, the three concepts should not be confused.

Finally, the distinction of the concepts of nationality and citizenship, relevant to note that article 22 of the Federal Constitution, which provides for the legislative competence of the Union, establishes in section XIII, as being the competent Union to legislate on "nationality, citizenship and naturalization," indicating that they are separate legal categories.

\section{NATIONALITY IN THE BRAZILIAN LAW}

\subsection{The criteria of concession and distinctions between birth and naturalized nationals}

In Brazil, the article 12, section I and II, the Republic Charter, defines who is a Brazilian national, and thus, who is a foreigner ${ }^{12}$.

In the law of a state which still has the remnants of a colonial empire, 'citizenship' may be limited to person with close connections with ('belongs to') the metropolitan territory, those belonging to its overseas territories having a separate status. Thus, the British Nationality Act 1981, as amended, distinguishes between three main categories: (1) British citizens - those belonging to the metropolitan territory of the United Kingdom, to the Channel Islands or to the Isle of Man, and now also to all remaining British overseas territories; (2) British Overseas Territories Citizens - persons who belonged to a former overseas territory but did not acquire the citizenship of that country on independence; and (3) British Nationals (Overseas) (former belongs of Hong Kong). Neverless, in international law, all those in the various categories are nationals of the United Kingdom, even though only British citizens are free of all UK immigration control."

11 TIBURCIO, Carmen. Human Rights of Aliens in International and Comparative Law. Haia: Martinus Nijhoff Publishers, 2001. p.1.

12 Article 12. "The following are Brazilians: (RCA No. 3, 1994; CA No. 23, 1999; CA No. 54, 2007) I - by birth: a) those born in the Federative Republic of Brazil, even if of foreign parents, provided that they are not at the service of their country; b) those born abroad, of a Brazilian father or a Brazilian mother, provided that either of them is at the service of the Federative Republic of Brazil; c) those born abroad, to a Brazilian father or a Brazilian mother, provided that they are registered with a competent Brazilian authority, or come to reside in the Federative Republic of 
The criterion for granting Brazilian nationality is primarily, the right of the soil (jus soli), there is, however, forecast of it being granted by the criterion of the right of blood (jus sanguinis).

Brazilian nationals are separated into two major groups in the constitutional provision: the native, whose nationality is original; and naturalized, whose nationality is acquired. The constitutional differentiation allows for the establishment of which rights are granted to one group and another. The $\S 2$ of Article 12 states that the law cannot make distinction between native and naturalized national, but the Constitution is allowed to do so. And it does so. The $\S 3$, of the same instrument, states that the President and Vice-President of the Republic; Presidents of the Chamber of Deputies and the Senate; Justice of the Supreme Court; and member of the diplomatic career; officer of the Armed Forces and State Defence Minister are exclusive for Brazilian born nationals.

As a result, the naturalized Brazilian could only occupy a seat in the Council of the Republic ${ }^{13}$, superior body for the consultation of the President, in the condition of deputy or senator or Minister of Justice, to the extent that the other participants (Vice-President of the Republic, President of the Chamber of Deputies, the Senate President and six native Brazilians ${ }^{14}$ older than thirty-five, two of which were appointed by the President, two elected by the Senate and two elected by the House) must be Brazilian born nationals.

The reason for these distinctions is strategic and intuitive, based

Brazil, and opt for the Brazilian nationality at any time after reaching majority; II - naturalized: a) those who, as set forth by law, acquire Brazilian nationality, it being the only requirement for persons originating from Portuguese-speaking countries the residence for one uninterrupted year and good moral repute; b) foreigners of any nationality, resident in the Federative Republic of Brazil for over fteen uninterrupted years and without criminal conviction, provided that they apply for the Brazilian nationality. Paragraph 1. The rights inherent to Brazilians shall be attributed to Portuguese citizens with permanent residence in Brazil, if there is reciprocity in favour of Brazilians, except in the cases stated in this Constitution. paragraph 2. the law may not establish any distinction between born and naturalized Brazilians, except in the cases stated in this Constitution. Paragraph 3. The following of ces are exclusive for born Brazilians: I - those of President and Vice-President of the Republic; II - that of President of the Chamber of Deputies; III - that of President of the Federal Senate; IV - that of Justice of the Supreme Federal Court; V - those of the diplomatic career; VI - that of of cer of the Armed Forces; VII - that of Minister of defense. Paragraph 4. Loss of nationality shall be declared for a Brazilian who: I - has his naturalization cancelled by court decision on account of an activity harmful to the national interests; II - acquires another nationality, save in the cases: a) of recognition of the original nationality by the foreign law; b) of imposition of naturalization, under the foreign rules, to the Brazilian resident in a foreign state, as a condition for permanence in its territory, or for the exercise of civil rights."

13 Article 89, of the Constitution

14 Article 89, section VI, of the Constitution 
on the commitment of what the constitutional legislator believes he has with the Federative Republic of Brazil, such, he has with this state a legal-political link originating at birth in the land or by the blood of his ancestors.

With regard to extradition, it is that a naturalized Brazilian, unlike the born Brazilian - who can never be extradited on any ground - can be delivered to a foreign jurisdiction provided that the extradition request is based on a previously committed crime prior to naturalization or in the case of request based on the charges of drug trafficking.

These are not the only distinctions. Article 222 of the Constitution establishes that the ownership of a newspaper, sound broadcasting, or any mass media must be exclusively by native Brazilians or those naturalized for more than ten (10) years. The distinction here is also strategic, with the aim of protecting national interest. With this, the prevention of a naturalized national or whose bond with the country is less than 10 years, to control the information flow in the country, through the mass media company of his possession.

The law, in turn, also makes distinction between birth or naturalized nationals. This is the case, for example, of the Consolidation of Labour Laws, Labour Code, which, in its article 353, establishes the protective regime to the Brazilian worker, that foreigners are second to Brazilians, subject to the exercise of professions reserved for native Brazilians or the Brazilians in general, it should be noted, in fact, that this distinction between born and naturalized nationals can never be done by infra standard for express constitutional provision. ${ }^{15}$

And when is a Brazilian a born or naturalized national? As mentioned, it is the Constitution that, in the exercise of Brazilian sovereignty, establishes who is the national, born or naturalized, and by exclusion foreigners. Also as we have seen, two criteria are used in Brazil for granting nationality by birth or original: the right of the soil, as a major criterion; and the right of blood, as a supplementary criterion. Anyway, before entering the constitutional formula, one must still make a last but relevant note about what is nationality by birth or original; and naturalization, or derivative.

The nationality by birth has a declaratory nature. In other words, is the one that we always recognize to have existed, even though such recognition can be given later in life, even in old age. It is the nationality by birth that allows, as a rule, the dual nationality phenomenon, insofar as, it is for each sovereign State to determine who is its nationals in the exercise of its sovereignty, not allowing a foreign state to determine who is or is not a national of another country, may be more than one sovereign state, by different criteria (right of blood, land rights,

15 Article12, Section 2, of the Constitution: "the law may not establish any distinction between born and naturalized Brazilians, except in the cases stated in this Constitution." 
marriage, adoption, religious criteria), bestow original nationality to the same individual, which makes one bear, different nationalities at the same time.

The nationality derived, or naturalization, is constitutive. Specifically, it is whereby one has a particular nationality, or no nationality (statelessness); and decides, at any given time, to establish legal and political relationship with a sovereign state, acquiring the nationality that one did not previously have. It is an acquired nationality.

\subsection{The constitutional rules}

\subsubsection{The acquisition}

The heading of Article 12 of the Political Charter says: "The following are Brazilians:”. The section I reveals, in its three paragraphs: $a, b$ and $c$, the chances that a Brazilian will be born a Brazilian. Let's us take a look at them. Paragraph $a$ : those born in Brazil, even if the parents are foreigners, provided they are not in the service of their country; paragraph $b$ : those born abroad, with a Brazilian father or mother, with either of the parents in the service of Brazil and paragraph $c$ : those born abroad of a Brazilian father or mother, provided they are registered in the office concerned or come to reside in Brazil, and in the latter case, choose, at any time after reaching the majority age, the Brazilian nationality.

Observe then let us find out what are the chances of a born Brazilian national examining closely, each of the possibilities of the constitutional text in its multiple regulatory possibilities.

The first hypothesis of nationality concession by birth is paragraph $a$, which adopts the criterion of right of the soil to grant it. A native Brazilian is one who is born in Brazil, even to foreign parents, except when they are in the service of their country. What is to be born in Brazil? A birth throughout Brazilian territory, which includes airspace and territorial sea, considered also are Brazilian ships and aircraft, public or in the service of the Brazilian government, wherever they are, or these same vessels and aircrafts, merchant or privately owned, which are in territories, airspace or the high seas that belongs to no sovereign State. This is the understanding that is extracted from the Brazilian legal system, considering, for example, legal rules of territoriality and extraterritoriality of the Brazilian criminal law. Article 5 of the Brazilian Penal Code states that, the Brazilian criminal law applies to crimes committed in the country, and then in $\S 1$ and $\S 2$, the Brazilian criminal law explains what it considers as national territory, incorporating in this concept, Brazilian ships and aircraft in the above situations. The Article 7 of the same Penal Code, reveals situations where, although committed abroad, the Brazilian criminal law can judge offenses, allowing us to 
conclude that, in the first case (art. 5) has the definition of the national territory as opposed to situations even abroad (art. 7), are considered crimes which could be judged by the Brazilian criminal law.

And the constitutional provision continues: even of foreign parents. That is, even though the parents of the new-born are both foreigners of the same nationality, or of different nationalities, or even without any nationality, and are only passing through the territory, the child born in Brazil will be Brazilian. At the point, we must remember what is seen as the dual nationality phenomenon. Will they just be Brazilians? To Brazil, yes; which does not stop, for example, the daughter of a French mother and German father, is also considered respectively in France and Germany, French and German, the criterion for granting nationality by birth or original, and by the right of blood.

However, the constitutional provision adds a caveat: will be Brazilian the new-born in the national territory, even if, of foreign parents, provided that they are not in the service of their country. Here, some questions arise in understanding the scope of the constitutional rule. Just one of the parents needs to be in service of their country, or both parents need to be the foreign service of their country? With the two being foreigners of different nationalities, finding just one of them in the service of their country, can one observe the constitutional restriction in the granting of original nationality to the child born here? It is necessary for the parents of the new-born to be in the service of their own countries or that they can simply be in the foreign service of any country? And even if, one of the parents, is in the service of his country, and the other is Brazilian? It is necessary that both parents are foreigners when one of them is in Brazil in the service of their country.

Taking premised on the legal nature of the fundamental right of nationality, it has the interpretation that the relevant constitutional provisions should always be less restrictive as possible. This framework, the standard that is extracted from the constitutional text should be understood this way: the new-born in Brazil will be a Brazilian, even if the parents are foreigners, except when both parents are foreign nationals and one or both are in the service of their country. So the newborn will be a Brazilian born in Brazil, even if: (i) one of the parents is a foreigner, in the service of their country, and the other is Brazilian. In this case, it must be considered that the child will be Brazilian by right of the soil, paragraph $a$, and by right of blood, paragraph $c$. It must also be considered that, otherwise, in the unusual situation where the same couple had this same child abroad, he would be Brazilian, based on paragraph $c$ of the same item I of Article 12, which is clearly not the same situation in relation to the equal treatment as to the child born in the country. Finally, one should not disregard the constitutional text, in paragraph $a$, which makes mention of both parents as foreigners "since 
these" and in the other paragraphs, $b$ and $c$, refers always to, father or mother, expressly; (ii) both parents are foreign nationals and one of them, or both, are in the service of a foreign state, which is not their country of nationality, so that an Arab, who represents in Brazil the interests of $\mathrm{Egypt}^{16}$, and has a child here, can have this child recognized as a born Brazilian. In this case, the seal is not strategic as in protecting national interests. It would deal, merely with, the profession of both or one parent.

The paragraph $b$, of section I of Article 12 states that new-borns overseas, to a Brazilian father or mother are Brazilians, provided that any of these is at the service of the Federative Republic of Brazil. This is the granting of original nationality by the criterion of the right of blood, in what is called jus sanguinis functional. And what is meant by being in the service of the Federative Republic of Brazil? Here, the criterion is the relationship of law under the legal and administrative system. In other words, the genitor must serve the interests of the country on official business. By the Federative Republic of Brazil, one must understand the Union and federal agencies, states and municipalities, and legal entities of public law that comprise the direct and indirect administrations, municipalities and public enterprises.

The paragraph $c$, of the same instrument provides that, those born abroad of a Brazilian father or mother are born Brazilians, provided that it is registered in the office concerned, or that resides in Brazil, and here, at any time after reaching legal age limit, might opt for Brazilian nationality. In the first case, there is the so-called jus sanguinis registry, i.e. the nationality by birth or original is granted by the criterion of the right of blood, therefore, the new-born in a foreign land is registered with the diplomatic mission office. This form of granting nationality, although traditional in the Brazilian Constitution, was withdrawn from the original 1988 Constitution and only reintroduced in 2007. This lapse has resulted in a multitude of problems that culminated in the jurisprudential construction, the Supreme Court, what is called original nationality under a suspensive condition. The record in the office concerned, which, as stated, was reintroduced in the Constitution by Amendment No. 54, 2007, gave rise, in law cases, the question of whether the text refers only to Brazilian diplomatic or consular offices abroad or also the individual notary registries in Brazil. It is that the transitional rule in Article 95 of $\mathrm{ADCT}^{17}$, also introduced in the Constitution by the such mention amendment, diplomatic and consular offices, or registry

16 In the case of diplomats, one cannot ignore that The Hague Convention on Nationality, 1930 provides that the children of these agents can break free of nationality acquired by right of the soil, when on mission, through mere resignation, freeing up thus also of the duties pertaining to nationality.

17 Temporary Constitutional Provisions Act (ADCT) 
office, if the child comes to live in Brazil. Thus, although it appears to have the intended constitutional legislator, resulting to refer only to Brazilian diplomatic or consular offices abroad, either because the registry in Brazil, although delayed, was always possible, by itself, and was never a concessive nationality criteria; that's because the rule of Article 95 of ADCT refers only to children born between 7 June 1994 and 21 September 2007, the fact is that a less restrictive interpretation would lead to the conclusion that one must understand the registry offices in Brazil are also attained by the text of paragraph $c$.

And the constitutional provision continues mentioning those born abroad, the children of a Brazilian father or mother, who come and reside in the country, at any time after the majority age limit, may opt for Brazilian nationality. In this case, no matter what age (from 18 years) the child of a Brazilian resides in the country. Equally it is unimportant whether or not he has mastered the language. Residing in Brazil, the child of a Brazilian may opt for nationality by birth or original. This nationality option is a judicial measure of voluntary jurisdiction, the authority of the Federal Court, for which it is legitimized for one to opt in his own name. In these procedures it is essential for the manifestation of the Federal Prosecution Service as a fiscal of the law, considering the nature of the action.

At the point, there is still the need to point out that Brazilian law does not confer nationality, original or derived, by adoption or marriage.

Now let's see when the Federative Republic of Brazil grants derivative nationality through naturalization. In other words: how do people who were not and want to be, become Brazilians.

Paragraphs $a$ and $b$ of section II of Article 12 of the Charter of the Republic, bring the chances of granting derived nationality. This nationality, as stated above, is constitutive, i.e., a foreigner becomes a national, distinguished, so that at some point in life, the Brazilian State has recognized this national as one, who had a different nationality from birth.

The paragraph $a$ refer to those who require it, according to the law. In this case, any foreigner can, following the requirements of sections I to VIII of Article 112 of Law 6.815/80 apply to the Minister of Justice for naturalization, basically, to foreigners originating from Portuguese speaking countries they only need to prove residence in Brazil for one uninterrupted year, and be of good moral character.

Having submitted the request to the Minister of Justice ${ }^{18}$, its

18 The procedure is governed by Law 6.815/80, in Articles 111 and later 116 and subsequent. Also by Decree 86.751/81, in Articles 119 to 134 . The granting of derived Brazilian nationality is given by the administrative rule of the Minister of Justice, which, pursuant to Article 119 of Law 6.815/80 shall issue a certificate on behalf of the naturalizing and will forward to the federal judge of the city where it is domiciled. It is in this locality, the 1st Court, where there 
concession is discretionary, because it is a sovereign act.

Naturalization doesn't matter if it is an acquisition of the Brazilian nationality by the spouse and the offspring of the naturalized, under Article 123 of the said legislation.

The paragraph $b$ of the same section II, takes care of the hypothesis of naturalization of a foreigner provided that he requests, of any nationality or no nationality, who is in the country for over fifteen uninterrupted years and without criminal conviction.

In this case, there is the amnesty naturalization call, which is the disregard of any irregularity in the permanence in Brazil. Here, with the constitutional requirements met, there is no discretion on the part of the Brazilian state. It is a subjective, constitutional right, to the Brazilian nationality. If the Constitution established the requirements for the obtainment, no margin was left to the Executive for considerations and opportunity convenience. But in the case of foreigners with Portuguese as the first language, referred to under paragraph $a$, would they also have a constitutional subjective right? No, because in this case there is an express reference to the law, which says "according to the law" and the law claims to grant derived nationality with a description of the Brazilian state.

In the case of naturalization by amnesty, there has to be a link established by the foreigner, who has to live here for over fifteen years, without any criminal conviction which is strong enough to allow him to obtain Brazilian nationality, regardless of the will of the governing, insofar as, the prediction is constitutional and does not refer to any law or regulation.

The question that arises is whether the settlement mentioned in the constitutional provision means formal and regular authorization to reside or just finding a legal fact, consistent in the foreigner's stay in the territory for a period established constitutionally, no matter their immigration status. A teleological interpretation of the rule does not authorize the exclusion of irregular immigrants from this constitutional case. If the intention is to grant amnesty, which is to regularize the situation of those who have established strong ties with the Brazilian government, then there is no reason to require of them an authorized and regular period of stay, so they can benefit from the constitutional

\footnotetext{
is more than one Federal Judgment, or at the Single court, where there is only one, the federal judge will deliver by filing of the requirements already mentioned in note $n^{\circ} 95$. It should be noted that, according to settled law - case of the Supreme Court (Extradition n ${ }^{\circ} 1074$, judged on February 14, 2008), "the granting of naturalization in our legal system, is an act that is within the mandate of the Minister of Justice, qualifying as an exclusive authority of the Executive Branch (Law 6.815/80, article 111.) -. the acquisition of the condition of a naturalised Brazilian, despite already granted by the Minister of Justice, will only occur after delivery, of the concerning naturalization certificate by a federal magistrate."
} 
permissive. This question, concerning the idea of residence in Brazil as a concept of authorized residence or a mere factual stay is, as we shall see, really relevant to inform the observance of rights and guarantees to the irregular foreigner who is in the territory, since it can anticipate the work that the Constitution considers when it refers to the foreign resident, this conceptual element of the instrument, residence, must be understood as a mere stay, for the purpose of obtaining rights.

Finally, in the case of public right, subjective, constitutional, to the Brazilian nationality, such that the derived nationality cannot be refused by the Brazilian State, to who fulfills the constitutionally listed requirements, it follows that the administrative rule of the Minister of Justice which grants naturalization in these cases is merely a declaratory character.

\subsubsection{Loss}

The Brazilian nationality is lost, constitutionally, in two cases, in accordance with sections I and II, and paragraphs $a$ and $b$, of the latter, $\S 4$ of Article 12: when, in the case of a naturalized Brazilian, the naturalization has been canceled by a court decision on account of an activity dangerous to national interest or; in the case of any Brazilian, born or naturalized, acquire another nationality, except in the case of recognition of foreign original nationality, in cases as we have seen, positive conflict of nationality, a phenomenon known as dual nationality, or by a foreign state imposing the exercise of any right to the Brazilian resident there.

In the case of a naturalized Brazilian, cancellation of the naturalization can only occur in a judiciary process. It is an action that investigates the harmful activity to national interest, allowing the naturalized Brazilian to defend himself. The judgment of the hurtful activity is made by the Federal Prosecution Service, which is legitimized for this action. The federal Parquet can act on its own initiative or caused by representation. The Federal Court is responsible for the prosecution and trial, which shows the obvious interest of the Union.

The wording of paragraph $a$ of section II, disregards the declaratory nature of the recognition of nationality by birth or original. It is that, the instrument talks about the acquisition of another nationality, when, in fact, technically, the dual citizenship phenomenon is found in the fact that the individual bear more than one original nationality, although this has not yet been recognized. As has already been said, the nature of the original nationality is declaratory. Its formal recognition by a foreign state operates as ex tunc, to the extent that it is not granted, but for mere recognition. The original nationality accompanies the individual from birth, and therefore does not interfere in constitutional terms, the legal and political relationship established between the 
Brazilian state and those bearing Brazilian nationality from birth.

The acquisition of another nationality by naturalization has always been, under Brazilian law, a form of losing the Brazilian nationality. In this situation, in which a new nationality is acquired, and the Brazilian nationality is lost, it values the volitional element to acquire it, to show some disregard for Brazilian nationality, birth or acquired by the Brazilian who acquires a new nationality. It is to say: who naturalizes assumes a new commitment to another sovereignty, which is not possible for the Brazilian constitution, to maintain its commitment to the Brazilian State as a result of this choice. Still based on the volitional element, is that the Constitution caveat of this loss, those who naturalize abroad not by their will, but pressed by circumstances, which can be checked by the terms "as a condition of residence in their territory" and " exercise of civil rights". This exception, introduced in the Constitution by the Constituent Reform Power, the Revision $\mathrm{n}^{\circ}$ 03, of 1994, aimed to ensure the many Brazilian immigrants who were compelled to naturalize abroad so as to live in minimum conditions of dignity in the countries where they go, and did not lose their original Brazilian nationality, to the extent that, they truly never wanted to miss it.

It turns out that the statement has a broad spectrum that, in practice, the Ministry of Justice rarely opens administrative process for loss of Brazilian nationality due to naturalization. In the vast majority of cases, it appears that the factual situations subsume to the hypothesis of paragraph $b$, section II of the $\S 4$ of Article 12, the Constitution.

Brazil admits, for over a century, the loss of nationality but; on the other hand, today, considered the legal nature of a fundamental right, it is as if they had not overcome the principle once subject, always subject.

\section{CONCLUSION}

Brazilian law has the rule of the right of the soil as a major criterion for granting Brazilian nationality, without, however, dispense with the additional criterion of the right of blood. adoption.

Brazilian nationality is not acquired by marriage; either by

The bond of nationality, as well as rights derive some obligations such as the obligation to vote, in which coincides with the concept of sovereignty, or serve on a jury.

Only nationals have constitutionally political rights ${ }^{19}$.

Possession of other original nationalities do not spring legal

19 Article 14, paragraph2: “foreigners cannot register as voters and neither can conscripts during their period of compulsory military service; 
consequences relating to the Brazilian nationality; however, the voluntary acquisition of another nationality through naturalization triggers their loss.

\section{REFERENCES}

AUST, Antony. Handbook of International Law. $2^{\text {a }}$ reprinted. Cambridge: Cambridge University Press, 2009

CAHALI, Yussef Said. Estatuto do Estrangeiro. 2a ed. Revista, atualizada e ampliada. São Paulo: Editora Revista dos Tribunais, 2010

DOLINGER, Jacob. Direito Internacional Privado. Parte Geral. 7a ed. Ampliada e Atualizada com as Emendas à Constituição e o novo Código Civil. Rio de Janeiro: Renovar, 2003.

MARINHO, Ilmar Penna. Tratado Sobre a Nacionalidade. Volume Primeiro. Direito Internacional da Nacionalidade. Rio de Janeiro: Departamento de Imprensa Nacional, 1956

TIBURCIO, Carmen. Human Rights of Aliens in International and Comparative Law. Haia: Martinus Nijhoff Publishers, 2001 